\title{
Improving the quality of the mechanical systems by specific methods in connection with a commercial entity
}

\author{
Claudiu Babis ${ }^{1, *}$, Andrei Dimitrescu ${ }^{1}$, Gabriel Iacobescu ${ }^{1}$, Gheorghe Solomon ${ }^{1}$, and Dan \\ Nitoi $^{1}$ \\ ${ }^{1}$ Politehnica University of Bucharest, Materials and Welding Technology Department, 313 Splaiul \\ Independenței, 060042, Bucharest, Romania
}

\begin{abstract}
This paper aims is improving the quality of mechanical systems, using specific methods. In the first part of the paper, we will identify the causes of non-quality, using ISCHIKAWA diagram. Based on data collected from economic entity studied, using PARETO chart, we will identify the main action. In the second part of the paper, we will implement the specific quality improvement methods for mechanical systems, previously identified. In the last part of the paper, based on new data collected from ecnomic entity, it will make a statistical prediction quality for the next period.
\end{abstract}

\section{Introduction}

Product quality is the primary factor in the development of any organization, hence the importance of a quality management system. [1]

The concept of quality has evolved over the years, due to the industrial and information society development. In time, quality evolves from quality control, to quality assurance and then to total quality, taking into account both the social component (staff involvement, participation) and economic component (the organization's image, reducing quality costs).

The analysed company MGC INTERNATIONAL INVESTMENTS Ltd. has more then 1600 employees in several factories in Romania, with a production of 300 tons of finished product per week. The company produces and sales canned vegetables and fruit, canned meat and mixed.

The main objectives of the study are set out in the quality policy statement of the general manager: increasing the number of customers in the European market, reducing the number of complaints by $40 \%$ over the previous year and reducing production costs.

This study is significant because the analyzed company has the most important role in the labor market in the area.

\footnotetext{
*Corresponding author: claudiubbs@gmail.com
} 


\section{Sampling data}

The Company has proposed implementing food safety management system in accordance with the requirements of SR EN ISO 22000/2005, which is described in the Handbook of Food Safety Management System (HFSMS).

Food Safety Management System (FSMS) described in this handbook sets out measures to demonstrate the application of the requirements of the aforementioned standard and the performance and capability of the organization in terms of providing consistent products with improved safety for consumers.

To operate legally and in good condition and meet the wishes of the beneficiaries in terms of quality of the finished product, proving the implementation of all laws and regulations in force, both in Romania and the European Union, the company has implemented the HACCP (Hazard Analysis and Critical Control Points) system, with the organizational procedures and implemented by this system by granting decisions by all team member.

They established checkpoints (CP) and critical control points (CCP) and were implemented proceedings and recording of data obtained at their level. This data is collected from the measuring and control instruments (AMC) and to the accompanying documents. All data is used to determine if it violates the law (temperature, microbiological parameters and physicochemical parameters). This data is archived electronically and on paper due to the possibility of establishing traceability of a finished product.

In developing the concepts of quality control, and quality assurance and subsequent total quality control were gradually developed a number of methods, tools and techniques that contribute to quality improvement. [2]

As no improvement action should not be employed without relying on data, this paper proposes a study of the relationship between cause and effect that they produce, and finding solutions to problems based on causes that led to negative effects on MGC INTERNATIONAL INVESTMENTS Ltd.

This study will be highlighted by cause and effect diagram (Ishikawa), shown in Figure 1 where the causes of non-complying products for human consumption correspond 6M: environment, labor, measurement, management, machinery, materials. [4]

The main advantage of Ishikawa diagram is highlights the 6 groups all causes of nonquality products. Another advantage is that for each group may consult various departments within the company. Main disadvantage is relatively long duration for proper preparation of this diagram.

Fishbone Diagram

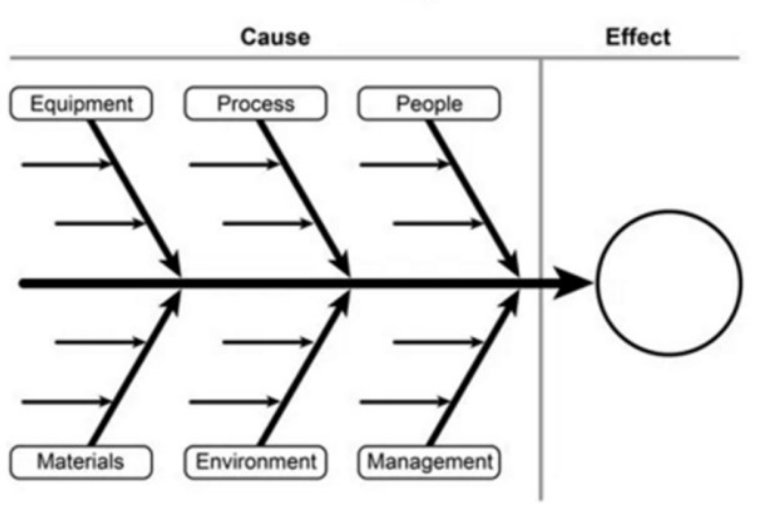

Fig. 1. Ishikawa Diagram 
The analysis was conducted by quantifying the nonconformity products and analyzing the causes of non-compliant products for a period of 30 days.

Thus, resulting the following histograms for the non-compliant products in groups. It should be noted that these data were obtained from the department for products checking inside the factory prior to marketing.

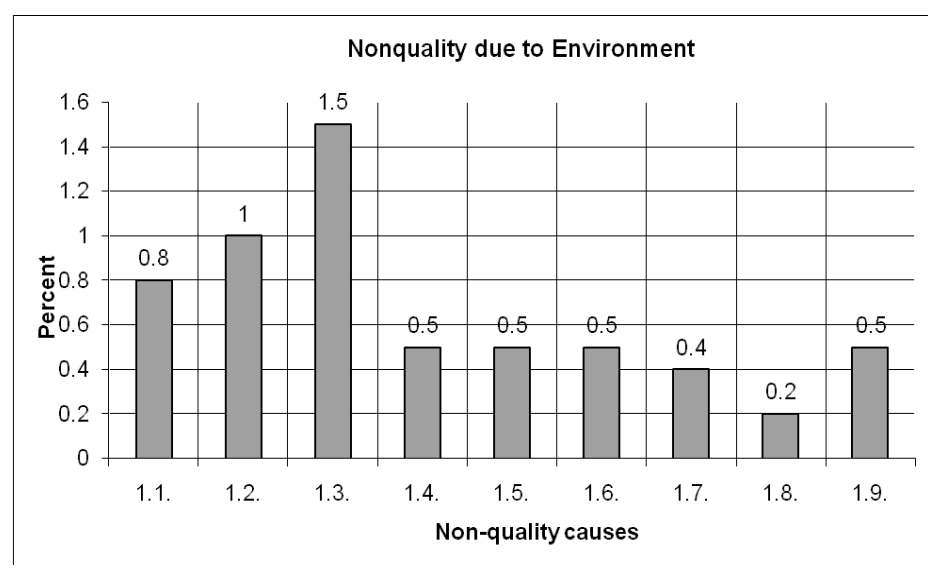

Fig. 2. Non-quality due to environment

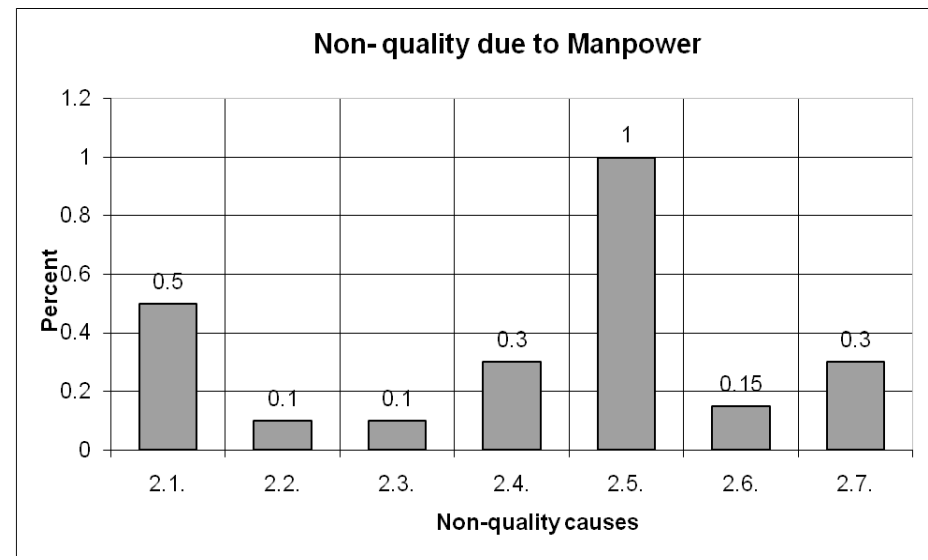

Fig. 3. Non-quality due to manpower

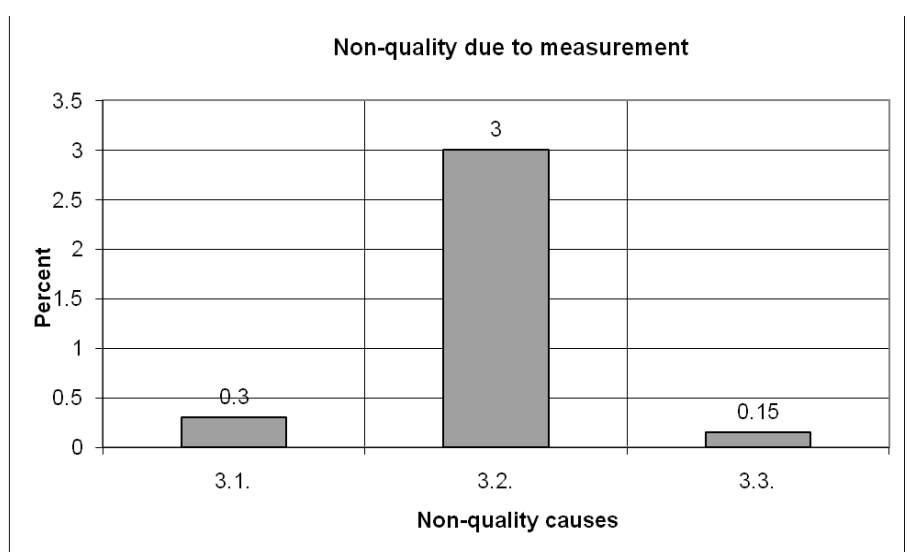

Fig. 4. Non-quality due to measurement 


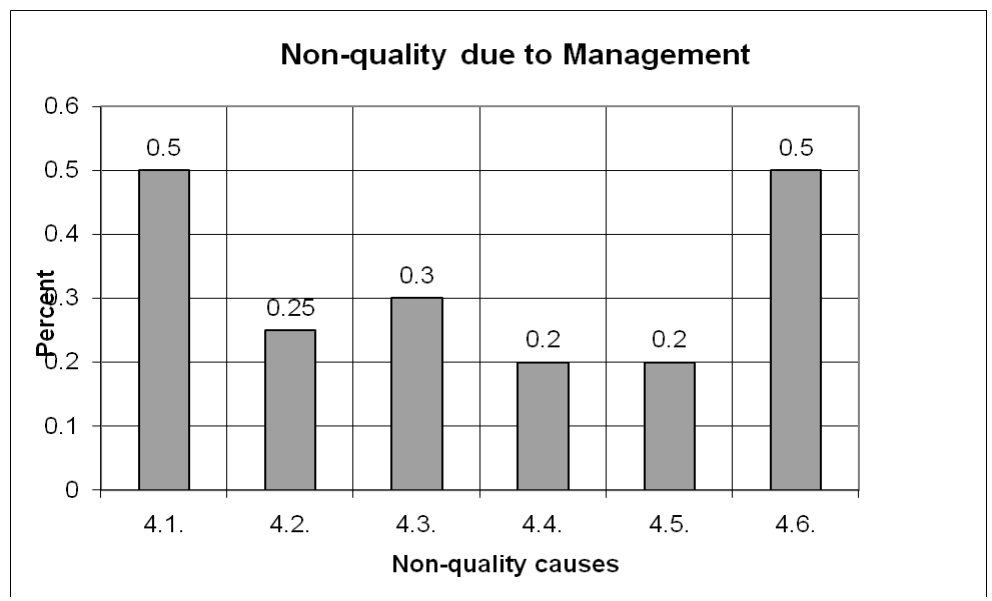

Fig. 5. Non-quality due to Management

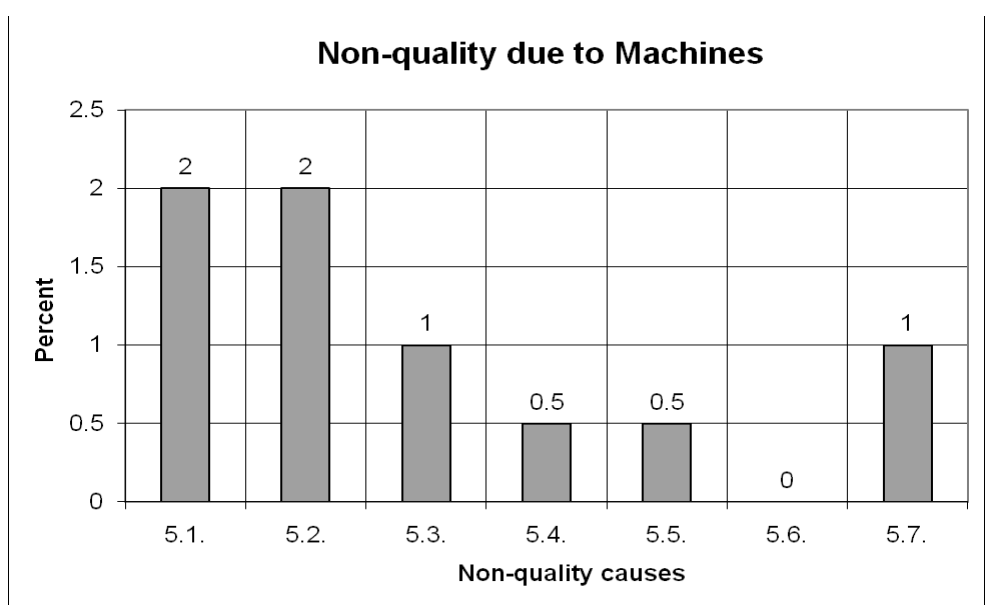

Fig. 6. Non-quality due to Machines

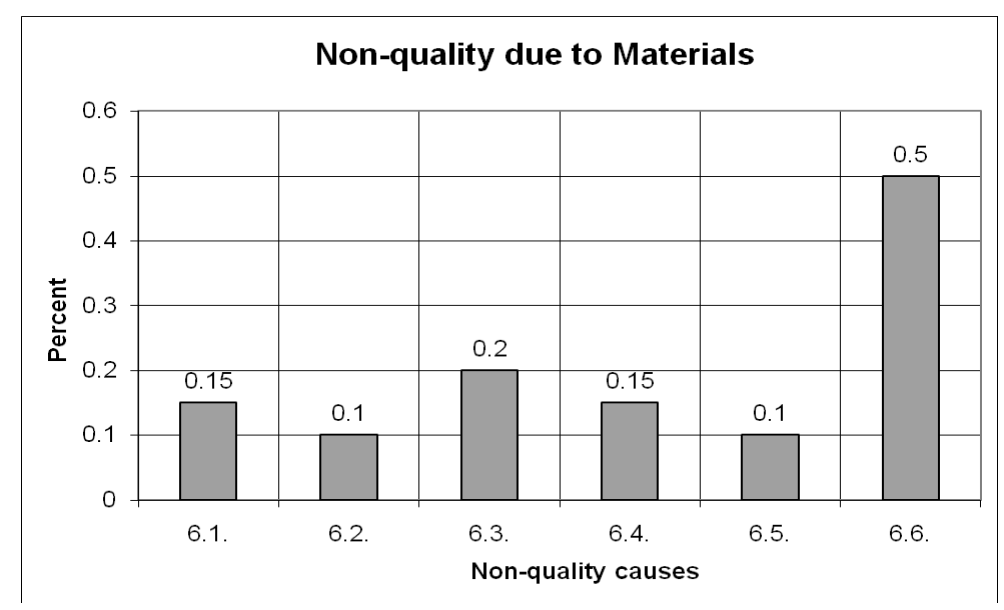

Fig. 7. Non-quality due to Materials 
The table below highlights the percentages of influence of all causes of non-conformity of the finished product:

Table 1. Cases of non-conformity according to Ishikawa diagram

\begin{tabular}{|c|c|c|c|}
\hline No. & Cause & Subcauses & $\begin{array}{c}\text { Non- } \\
\text { conformity } \\
{[\%]}\end{array}$ \\
\hline 1. & \multirow[t]{9}{*}{ 1. Environment } & 1.1. Lighting & 0,8 \\
\hline 2. & & 1.2.Ventilation & 1 \\
\hline 3. & & 1.3. Technical suspended routes & 1,5 \\
\hline 4. & & 1.4. Cleanliness & 0,5 \\
\hline 5. & & 1.5. Disinfection & 0,5 \\
\hline 6. & & 1.6. Equipment sanitation & 0,5 \\
\hline 7. & & 1.7. Staff hygiene & 0,4 \\
\hline 8. & & 1.8. Protection equipment & 0,2 \\
\hline 9. & & 1.9. Bacteria removal system & 0,5 \\
\hline 10. & \multirow[t]{7}{*}{ 2. Manpower } & 2.1. Good practices & 0,5 \\
\hline 11. & & 2.2. Staff training in the workplace & 0,1 \\
\hline 12. & & 2.3. Instructing & 0,1 \\
\hline 13. & & 2.4. Lack of financial motivation & 0,3 \\
\hline 14. & & 2.5. Training for equipment handling & 1 \\
\hline 15. & & 2.6. Working program & 0,15 \\
\hline 16. & & 2.7. Operators health check & 0,3 \\
\hline 17. & \multirow[t]{3}{*}{ 3.Measurement } & $\begin{array}{l}\text { 3.1. Installations to measure the weight of raw } \\
\text { materials, finished products }\end{array}$ & 0,3 \\
\hline 18. & & 3.2. Temperature measurement system & 3 \\
\hline 19. & & 3.3. Optimization of packaging - sensors & 0,15 \\
\hline 20. & \multirow[t]{6}{*}{ 4.Management } & 4.1. $\mathrm{PO}$ and $\mathrm{PL}$ procedures & 0,5 \\
\hline 21. & & 4.2. Employees information system - production stage & 0,25 \\
\hline 22. & & 4.3. Finished products transportation system & 0,3 \\
\hline 23. & & 4.4. Contracts with raw material suppliers & 0,2 \\
\hline 24. & & 4.5. Product sale system & 0,2 \\
\hline 25. & & 4.6. Marketing system & 0,5 \\
\hline 26. & \multirow[t]{7}{*}{ 5. Machines } & 5.1. Harvesters & 2 \\
\hline 27. & & 5.2. Transport & 2 \\
\hline 28. & & 5.3. Washing and sorting machine & 1 \\
\hline 29. & & 5.4. Processing & 0,5 \\
\hline 30. & & 5.5. Weighing and packaging machines & 0,5 \\
\hline 31. & & 5.6. Vacuum machines & 0 \\
\hline 32. & & 5.7. Maintenance & 1 \\
\hline 33. & \multirow[t]{6}{*}{ 6.Materials } & 6.1. Raw material suppliers database & 0,15 \\
\hline 34. & & 6.2. Providers Classification by quality / price & 0,1 \\
\hline 35. & & $\begin{array}{l}\text { 6.3. Classification of suppliers based on timeliness of } \\
\text { delivery }\end{array}$ & 0,2 \\
\hline 36. & & 6.4. Linking the two classifications & 0,15 \\
\hline 37. & & 6.5. Third party audits & 0,1 \\
\hline 38. & & 6.6. Archiving according raw material documents & 0,5 \\
\hline
\end{tabular}




\section{Conclusions}

Unable to act cumulatively to all causes of non-quality or because of organizational of financial reasons, it is necessary to decrease significantly the percentage of not complying products with minimum effort. Thus, actions have yield from all points of view.

To know in detail this phenomenon it must be applied another quality analysis which is called "Pareto Analysis".

Pareto analysis is a statistical technique for classifying tasks small in number but with significant effect. It is based on the Pareto principle (also known as the 80/20 rule), which states that $20 \%$ of resources generates $80 \%$ of total labor, or in terms of quality improvement, most of the problems (80\%) have several key causes (20\%). [3]

Pareto chart helps management interventions methodically through action plans built around the major causes of emerged problems, by being a strongly visually oriented, to make the decision. It is a tool for qualitative analysis because it focuses on process parameters in terms of frequency. Defined parameters can be events, errors, features, etc.

Of the 38 non-quality causes $20 \%$ representing 7.4 causes. The following eight causes were chosen as representative:

Table 2. Cases of non-conformity according to Pareto Analysis

\begin{tabular}{|c|c|c|c|}
\hline No. & Cause & Subcause & Non-conformity [\%] \\
\hline 1 & \multirow[t]{2}{*}{ 1.Environment } & 1.2. Ventilation & 1 \\
\hline 2 & & 1.3. Technical suspended routes & 1,5 \\
\hline 3 & 2.Manpower & 2.5. Equipment handling training & 1 \\
\hline 4 & 3.Measurment & 3.2. Temperature measurement system & 3 \\
\hline 8 & \multirow[t]{4}{*}{ 5.Machines } & 5.1. Harvesters & 2 \\
\hline 9 & & 5.2. Transport & 2 \\
\hline 10 & & 5.3. Washing and sorting & 1 \\
\hline 11 & & 5.4. Maintenance & 1 \\
\hline
\end{tabular}

After corrective actions listed above causes and establish new percentage of noncompliant products, where they exist we can start the depreciation of these corrective actions.

Using specific programs, we can predict when they will recoup their investments and especially what are the company's gross earnings. It should be noted that these calculations have real value only if it does not change the parameters, for example the average sales prices of products and raw materials or other taxes, contributions and excises.

For correct predictions, we suggest the use of higher mathematics regression curves with equal residuals and standard errors that tend to 1 . These curves we aim to generate with the soft CurveExpert 1.4 after taking data from the company.

\section{References}

1. Bernard Froman, Managementul Calitatii, 77, (Ed. Tehnica, Bucuresti, 1998)

2. Henri Mitonneau, O noua orientare in Managementul Calitatii, 12, (Ed. Tehnica, Bucuresti, 1998)

3. Arthur L.J., Rapid Evolutionary Development - Requirements, Prototiping \& Software Creation, (Ed. John Wiley\&Sons, 2011)

4. Boca Dana, Bazele managementului calității în afaceri, (Ed. Risoprint, 2013) 